\title{
Corona Discharge Power of Plasma Treatment Influence on the Physicochemical and Microbial Quality of Enoki Mushroom (Flammulina velutipes)
}

\author{
Nguyen Phuoc Minh \\ Institute of Applied Technology, Thu Dau Mot University, Binh Duong Province, Vietnam.
}

\begin{abstract}
Plasma treatment was widely known as an effective technology applied for contact-surface decontamination. Enoki (Flammulina velutipes) was an edible-medicinal mushroom with different phytochemicals and bioactive components beneficial for human health. Enoki mushroom had high respiration rate therefore it was highly perishable after harvesting. Moreover, it was greatly susceptible to microbial contamination but it was not feasible to be decontaminated by normal water washing. It's urgent to extend shelf-life and control microbial criteria on this mushroom in dry manner without aqueous treatment. Corona discharge plasma was among 4 kinds of diverse cold atmospheric pressure plasma sources widely applied in food industry. This study demonstrated the influence of corona discharge plasma power values (control, 120, 150, 180, $210 \mathrm{~W}$ ) on the physicochemical and microbial characteristics of Enoki mushroom during 10 days of storage at ambient temperature. Results showed that Enoki mushroom should be treated at $150 \mathrm{~W}$ of corona discharge plasma power to retain weight loss, total soluble solid, vitamin $\mathrm{C}$ in acceptable values while reducing total Aerobic count, Coliform, Enterobacteriaceae as much as possible. At the $10^{\text {th }}$ day of storage, the weight loss, total soluble solid, vitamin C, total Aerobic count, Coliform, Enterobacteriaceae were recorded at $3.35 \pm 0.07 \%$, $6.98 \pm 0.03{ }^{\circ}$ Brix, $14.81 \pm 0.04 \mathrm{mg} / 100 \mathrm{~g}, 4.71 \pm 0.05 \mathrm{log} \mathrm{CFU} / \mathrm{g}, 3.17 \pm 0.02 \mathrm{log} \mathrm{CFU} / \mathrm{g}, 2.13 \pm 0.01 \mathrm{CFU} / \mathrm{g}$, respectively. Findings of this research proved that corona discharge plasma pretreatment would be appropriate to maintain physicochemical properties and retard microbial loads on Enoki mushroom during preservation.
\end{abstract}

Keywords: Enoki mushroom, microbial, physicochemical, corona discharge plasma

*Correspondence: nguyenphuocminh@tdmu.edu.vn

(Received: August 10, 2021; accepted: October 28, 2021)

Citation: Minh NP. Corona Discharge Power of Plasma Treatment Influence on the Physicochemical and Microbial Quality of Enoki Mushroom (Flammulina velutipes). J Pure Appl Microbiol. 2022;16(1):182-192. doi: 10.22207/JPAM.16.1.08

(C) The Author(s) 2022. Open Access. This article is distributed under the terms of the Creative Commons Attribution 4.0 International License which permits unrestricted use, sharing, distribution, and reproduction in any medium, provided you give appropriate credit to the original author(s) and the source, provide a link to the Creative Commons license, and indicate if changes were made. 


\section{INTRODUCTION}

Plasma treatments were widely applied in medicine, agriculture and postharvest sector. Different kinds of plasma technologies were classified as gases (air, nitrogen, helium, argon) and methods (plasma jet, corona discharge, gliding arc discharge, dielectric barrier discharge) to release plasma at atmospheric pressure and low temperature. ${ }^{1,2}$ The numerous benefits of plasma treatment included cost-effective running, simply convenient manipulation and environmentally protective friendliness. ${ }^{2,3}$ Plasma technology was successfully applied in sterilization of medical equipment, tooth bleaching. ${ }^{2}$ Plasma treatment could produce bioactive substances free from toxic residue. ${ }^{4}$ Plasma treatment were proven to be adaptable for germinating improvement, plant morphology, toxic decontamination, contactsurface disinfection (viruses, bacteria, fungi), enzyme retardation and shelf-life extension of fresh fruits and vegetables. ${ }^{5-8}$ In agriculture, under plasma treatment the out layer of the fragrant rice flour became more hydrophilic to uptake more moisture to reduce thermal treatment duration. ${ }^{9}$ The effectiveness of plasma technology relied on the reactor profile (electrode organize, length from the product layer) and the technical variables of the equipment (gas component, speed current, power, temperature, time). ${ }^{10-12}$ Corona discharge was released by using high voltage between two sharp electrodes. The corona discharge electrode was specified by a needle. The ionization emitted a beam surround this positive electrode. Corona charge had weak beam with low electron and ion energy. ${ }^{13}$ Enoki mushroom (Flammulina velutipes) was mostly planted for succulent and add-on aims ${ }^{14}$ This mushroom was rich in polysaccharide (both low-digestible and non-digestible), vitamin B1, mycosterol, dietary fiber contributing to the alleviation of blood sugar, blood cholesterol, hypertension, thrombotic, hypolipidemic, inflammation, cancer and tumor. ${ }^{15-22}$ Mycosterol could effectively minimize the total cholesterol and low density lipoprotein in blood and plasma. ${ }^{23}$

Polyphenol in Enoki mushroom was proven to be better prevention in probability of cardiovascular disease. ${ }^{24,25}$ Extract from Flammulina velutipes greatly scavenged $\alpha$ - $\alpha$,diphenylpicrylhydrazyl free radicals and presented reducing power. ${ }^{26}$ Flammulina velutipes powder and extract were useful on the lipid metabolism to decrease the low density lipoprotein of hamster. ${ }^{27}$ Due to attractive flavor, aroma, and nutritional proximate; Enoki mushroom was highly appreciated to be eaten in fresh or minimal processing; therefore microbial safety should be strictly paid attention. Enoki mushroom was commonly infected by foodborne-pathogen like Salmonella, Listeria, and E.coli. ${ }^{28-30}$ Both spoilage microorganisms were mainly responsible for quality degradation in Enoki mushroom at postharvest. It's necessary to control microbial contamination, maintain physicochemical attributes of Enoki mushroom in an extended shelf-life.

There were numerous strategies to resolve these problems based on physical and chemical approaches. ${ }^{31}$ Non-contact water treatment was highly preferred to avoid water remain on the surface that could seriously damage the integrity of mushroom by decay. Plasma jet treatment got a great attention due to its excellent efficacy in microbial decontamination proven on different products such as vegetable leaf, mung bean sprout, red chicory, citrus fruit. ${ }^{22-40}$ In one report, plasma activated water was applied to manage postharvest quality of button mushroom. ${ }^{41}$ In another study, pressure plasma jet was investigated the effectiveness of the treatment time to be effectively eliminate antimicrobial load on mushroom surface..$^{42}$ Similarly, plasma treatment was proven to be efficient to inactivate microorganisms on product's surface. ${ }^{43-46}$ Shelf-life of raw Enoki mushroom was normally about 2-3 days at normal condition. Purpose of our study was to find the appropriate method to extend its raw stability during post-harvest by verifying the influence of plasma jet power values on the physicochemical and microbial characteristics of Enoki mushroom during 10 days of storage at ambient temperature. Plasma treatment would be an efficient non-thermal treatment to avoid negative impact of heat on natural properties of this valuable mushroom.

\section{MATERIAL AND METHOD Material}

Enoki mushroom was harvested in farm of Soc Trang province, Vietnam. Chemical reagents such as oxalic acid, 2,6-dichlorophenol-indophenol reagent were all analytical grade. Corona discharge 
equipment (model HV-X10, Tantec) was used to treat Enoki mushroom. This equipment operated under mains voltage and frequency (100-240 VAC 50/50 Hz), output voltage/power (Max. 400 $\mathrm{Vp} / 0-1000 \mathrm{Watt})$, power consumption (1200 VA), dimensions in mm (430 x $470 \times 200, \mathrm{LxW} \times \mathrm{H})$.

\section{Researching method}

In this research, the corona discharge plasma treatment time $3 \mathrm{~min}$ and oxygen flow rate $0.6 \mathrm{~mL} / \mathrm{min}$ were fixed while the power was varied from 0-210 W. After treatment, the enoki mushroom was packed in vacuum bag and stored at ambient temperature for 10 days. In two-day interval, 15 samples were taken to evaluated the weight loss, total soluble solid, ascorbic acid, total plate count, Coliform and Enterobacteriaceae. Weight loss (\%) was examined by comparing the reduction percentage of the initial weight and the weight at sampling interval. Total soluble solid ('Brix) was evaluated by hand-held refractometer (Atago, model: Master-53M). Ascorbic acid content $(\mathrm{mg} / 100 \mathrm{~g})$ was determined by applying a 2,6-dichlorophenol indophenol manual titration protocol. Total Aerobic count (log CFU/g), Coliform (log CFU/g), Enterobacteriaceae (log CFU/g) were enumerated by $3 \mathrm{M}$-petrifilms. The $3 \mathrm{M}^{\mathrm{TM}}$ Petrifilm ${ }^{\mathrm{TM}}$ Aerobic Count Plate was a ready-made culture medium system that contained modified Standard Methods nutrient, a cold-water-soluble gelling agent and an indicator that facilitates colony enumeration. The $3 \mathrm{M}^{\mathrm{TM}}$ Petrifilm ${ }^{\mathrm{TM}}$ Coliform, Enterobacteriaceae Count Plate were sampleready-culture medium systems that contained modified Violet Red Bile Glucose (VRBG) nutrient, a cold-water-soluble gelling agent, and a tetrazolium indicator that facilitates colony enumeration. $5 \mathrm{~g}$ of sample was blended with $45 \mathrm{ml}$ of phosphate buffer dilution. Lifting the top film, $1 \mathrm{~mL}$ of sample suspension was dispensed onto the center of bottom film, leaving the top film down. The counting plates were incubated at $34-37^{\circ} \mathrm{C}$ in $48 \pm 2$ $\mathrm{h}$ for total Aerobic count; $44^{\circ} \mathrm{C} \pm 1^{\circ} \mathrm{C}$ in $24 \mathrm{~h} \pm 2 \mathrm{~h}$ for Coliform; $34-37^{\circ} \mathrm{C}$ in $24 \pm 2 \mathrm{~h}$ for Enterobacteriaceae in a horizontal position by incubator (model IF450, Memmert). Red colonies without closely associated gas bubbles was identified as coliform. Enterobacteriaceae colonies would appear as red colonies associated with yellow zones, red colonies associated with gas bubbles, red colonies associated with yellow zones and with gas bubbles (according to The $3 \mathrm{M}^{\mathrm{TM}}$ Petrifilm ${ }^{\mathrm{TM}}$ Aerobic, Coliform and Enterobacteriaceae Interpretation Guide). Total Aerobic count, Coliform and Enterobacteriaceae were counted with the $3 \mathrm{M}^{\mathrm{TM}}$ Petrifilm ${ }^{\mathrm{TM}}$ Plate Reader. According to Food Standards Australia New Zealand 2016 at website: http://www.foodstandards.gov.au and http:// www.foodstandards.govt.nz, the acceptable limits of microorganisms in ready-to-eat foods like fresh fruits and vegetables were not applicable for total Aerobic count (log CFU/g), coliform (4 log CFU/g), and Enterobacteriaceae (4 log CFU/g).

The reason for analyzing only these microbiological parameters and no others could be explained that they were the most popular hygienic indicators represented as quality criteria for this kind of product.

\section{Statistical analysis}

All tests were arranged in three replications. The values were expressed as average \pm standard deviation. Statistical summary was executed by the Statgraphics Centurion version XVI.

\section{RESULT AND DISCUSSION Physicochemical properties Weight loss}

The effect of corona discharge plasma power (control, 120, 150, 180, $210 \mathrm{~W}$ ) on the weight loss of Enoki mushroom was presented in Table 1. It's rather easy to notice that there was a gradual increment of weight loss during storage. Weight reduction could be due to water loss during mushroom respiration. ${ }^{41}$ Weight loss was not beneficial for mushroom because it caused a remarkable tissue shrinkage leading to negative appearance as well as commercial value. Therefore, weight loss should be minimal. The greatest weight loss was occurred on Enoki mushroom pretreated at $210 \mathrm{~W}(2.12 \pm 0.05$ to $6.10 \pm 0.06 \%)$ while the lowest weight loss was noticed on control sample $(0.19 \pm 0.11$ to $2.61 \pm 0.03$ $\%)$. There was no significant difference of weight loss among control sample, sample pretreated at $120 \mathrm{~W}$ and sample pretreated at $150 \mathrm{~W}$. Under the treatment of corona discharge plasma power 150 W, the weight loss of Enoki mushroom increased from $0.63 \pm 0.04 \%$ at the 2 nd day to $3.35 \pm 0.07$ $\%$ at the 10th day. Our result was in accordance with finding a similar report. Weight loss was 
higher in mushroom treated with pressure plasma compared to the control. ${ }^{42}$

\section{Total soluble solid}

Total soluble solid content $(8.13 \pm 0.01$ 'Brix) of Enoki mushroom was analyzed by handheld refractometer in the 1st day of storage. There was slight degradation of total soluble solid content in all groups during storage. At the $10^{\text {th }}$ day of storage, the lowest total soluble solid content $\left(6.58 \pm 0.04^{\circ} \mathrm{Brix}\right)$ was noticed in the Enoki mushroom pretreated by corona discharge plasma power $210 \mathrm{~W}$; meanwhile the highest total soluble solid content $\left(7.37 \pm 0.04{ }^{\circ} \mathrm{Brix}\right)$ was recorded in the control. There was no significant difference of total soluble solid content among control sample, sample pretreated at $120 \mathrm{~W}$ and sample pretreated at $150 \mathrm{~W}$. Under the treatment of corona discharge plasma power $150 \mathrm{~W}$, the total soluble solid content of Enoki mushroom remained $6.98 \pm 0.03^{\circ} \mathrm{Brix}$ the $10^{\text {th }}$ day of storage (Table 2).

\section{Ascorbic acid content}

Total ascorbic acid content $(16.49 \pm 0.03$ $\mathrm{mg} / 100 \mathrm{~g}$ ) of Enoki mushroom was analyzed by applying a 2,6-dichlorophenol indophenol manual titration in the $1^{\text {st }}$ day of storage. There was gradual decomposition of ascorbic acid

Table 1. Weight loss (\%) of Enoki mushroom pretreated by corona discharge plasma power (W)

\begin{tabular}{lccccc}
\hline $\begin{array}{l}\text { Plasma power } \\
\text { (W) }\end{array}$ & 2 & \multicolumn{5}{c}{$\begin{array}{c}\text { Storage (days) } \\
\end{array}$} & 4 & 6 & 8 & 10 \\
\hline Control & $0.19 \pm 0.11^{\mathrm{c}}$ & $0.54 \pm 0.06^{\mathrm{c}}$ & $1.07 \pm 0.05^{\mathrm{c}}$ & $1.84 \pm 0.06^{\mathrm{c}}$ & $2.61 \pm 0.03^{\mathrm{c}}$ \\
120 & $0.27 \pm 0.06^{\mathrm{c}}$ & $0.61 \pm 0.08^{\mathrm{c}}$ & $1.18 \pm 0.08^{\mathrm{c}}$ & $1.93 \pm 0.09^{\mathrm{c}}$ & $2.80 \pm 0.08^{\mathrm{c}}$ \\
150 & $0.63 \pm 0.04^{\mathrm{bc}}$ & $1.04 \pm 0.05^{\mathrm{bc}}$ & $1.72 \pm 0.07^{\mathrm{bc}}$ & $2.41 \pm 0.06^{\mathrm{bc}}$ & $3.35 \pm 0.07^{\mathrm{bc}}$ \\
180 & $1.04 \pm 0.07^{\mathrm{b}}$ & $1.61 \pm 0.06^{\mathrm{b}}$ & $2.23 \pm 0.09^{\mathrm{b}}$ & $2.86 \pm 0.08^{\mathrm{b}}$ & $3.62 \pm 0.09^{\mathrm{b}}$ \\
210 & $2.12 \pm 0.05^{\mathrm{a}}$ & $3.25 \pm 0.07^{\mathrm{a}}$ & $4.17 \pm 0.08^{\mathrm{a}}$ & $5.06 \pm 0.07^{\mathrm{a}}$ & $6.10 \pm 0.06^{\mathrm{a}}$ \\
\hline
\end{tabular}

Values were the mean of three replications; Values in row followed by the same letter/s were not differed significantly $(\alpha=\mathrm{P}=0.05)$.

Table 2. Total soluble solid (oBrix) of Enoki mushroom pretreated by corona discharge plasma power (W)

\begin{tabular}{lccccc}
\hline \multicolumn{2}{l}{$\begin{array}{l}\text { Plasma power } \\
\text { (W) }\end{array}$} & 2 & 4 & \multicolumn{5}{l}{ Storage (days) } \\
& & & 6 & 8 & 10 \\
\hline Control & $8.02 \pm 0.04^{\mathrm{a}}$ & $7.95 \pm 0.01^{\mathrm{a}}$ & $7.84 \pm 0.03^{\mathrm{a}}$ & $7.62 \pm 0.02^{\mathrm{a}}$ & $7.37 \pm 0.04^{\mathrm{a}}$ \\
120 & $8.00 \pm 0.03^{\mathrm{a}}$ & $7.87 \pm 0.02^{\mathrm{a}}$ & $7.75 \pm 0.04^{\mathrm{a}}$ & $7.54 \pm 0.03^{\mathrm{a}}$ & $7.29 \pm 0.02^{\mathrm{a}}$ \\
150 & $7.99 \pm 0.05^{\mathrm{a}}$ & $7.61 \pm 0.03^{\mathrm{ab}}$ & $7.43 \pm 0.01^{\mathrm{ab}}$ & $7.21 \pm 0.04^{\mathrm{ab}}$ & $6.98 \pm 0.03^{\mathrm{ab}}$ \\
180 & $7.97 \pm 0.02^{\mathrm{a}}$ & $7.45 \pm 0.04^{\mathrm{b}}$ & $7.17 \pm 0.02^{\mathrm{b}}$ & $7.02 \pm 0.03^{\mathrm{b}}$ & $6.67 \pm 0.02^{\mathrm{b}}$ \\
210 & $7.96 \pm 0.04^{\mathrm{a}}$ & $7.38 \pm 0.02^{\mathrm{b}}$ & $7.09 \pm 0.03^{\mathrm{b}}$ & $6.95 \pm 0.01^{\mathrm{b}}$ & $6.58 \pm 0.04^{\mathrm{b}}$
\end{tabular}

Values were the mean of three replications; Values in row followed by the same letter/s were not differed significantly $(\alpha=P=0.05)$

Table 3. Ascorbic acid (mg/100g) of Enoki mushroom pretreated by corona discharge plasma

\begin{tabular}{|c|c|c|c|c|c|}
\hline \multicolumn{3}{|c|}{ Plasma power } & \multicolumn{3}{|l|}{ Storage (days) } \\
\hline$(W)$ & 2 & 4 & 6 & 8 & 10 \\
\hline Control & $16.35 \pm 0.04^{a}$ & $16.19 \pm 0.03^{\mathrm{a}}$ & $15.87 \pm 0.02^{\mathrm{a}}$ & $15.52 \pm 0.04^{\mathrm{a}}$ & $15.17 \pm 0.05^{\mathrm{a}}$ \\
\hline 120 & $16.29 \pm 0.03^{a}$ & $16.10 \pm 0.05^{\mathrm{a}}$ & $15.76 \pm 0.06^{a}$ & $15.41 \pm 0.05^{\mathrm{a}}$ & $15.09 \pm 0.03^{a}$ \\
\hline 150 & $16.01 \pm 0.05^{\mathrm{ab}}$ & $15.83 \pm 0.06^{\mathrm{ab}}$ & $15.28 \pm 0.04^{\mathrm{ab}}$ & $15.03 \pm 0.03^{\mathrm{ab}}$ & $14.81 \pm 0.04^{\mathrm{ab}}$ \\
\hline 180 & $15.73 \pm 0.04^{b}$ & $15.39 \pm 0.03^{b}$ & $14.97 \pm 0.05^{b}$ & $14.69 \pm 0.02^{b}$ & $14.32 \pm 0.01^{b}$ \\
\hline 210 & $15.08 \pm 0.06^{c}$ & $14.60 \pm 0.04^{c}$ & $14.04 \pm 0.03^{c}$ & $13.18 \pm 0.04^{c}$ & $12.27 \pm 0.05^{c}$ \\
\hline
\end{tabular}

Values were the mean of three replications; Values in row followed by the same letter/s were notdiffered significantly $(\alpha=P=0.05)$. 
content in all groups during storage. At the 10th day of storage, the lowest ascorbic acid content $(12.27 \pm 0.05 \mathrm{mg} / 100 \mathrm{~g})$ was noticed in the Enoki mushroom pretreated by corona discharge plasma power $210 \mathrm{~W}$; meanwhile the highest ascorbic acid content $(15.17 \pm 0.05 \mathrm{mg} / 100 \mathrm{~g})$ was recorded in the control. There was no significant difference of ascorbic acid content among control sample, sample pretreated at $120 \mathrm{~W}$ and sample pretreated at $150 \mathrm{~W}$. Under the treatment of corona discharge plasma power $150 \mathrm{~W}$, the ascorbic acid content of Enoki mushroom remained $14.81 \pm 0.04 \mathrm{mg} / 100 \mathrm{~g}$ at the $10^{\text {th }}$ day of storage (Table 3 ).

As above mentioned, table 1-3 showed the impact of corona discharge plasma treatment to physicochemical characteristics like weight loss, total soluble solid, and ascorbic acid content of
Enoki mushroom during storage. Stability of total soluble solid and ascorbic acid could be varied depending on the plasma operating variables; power was a case in point. ${ }^{10,47}$ The low penetration depth of the plasma radiation was beneficial to retain more thermal-sensitive constituents inside the matrix. Plasma treatment at high dosage could negatively affect to physicochemical properties and shelf-life of products as well as consumer acceptability. ${ }^{48}$ Plasma treatment released the reactive oxygen-based species and reactive nitrogen-based species which directly altered biochemical processes like higher growth hormones and metabolites induced to biosynthesis more total soluble solid and ascorbic acid. ${ }^{49}$ Corona discharge of plasma treatment was demonstrated to effectively eliminated ethylene

Table 4. Total Aerobic count, coliform count and Enterobacteriaceae count (log CFU/g) of Enoki mushroom pretreated by corona discharge plasma power (W) at day zero

\begin{tabular}{|c|c|c|c|c|c|}
\hline Plasma power (W) & Control & 120 & 150 & 180 & 210 \\
\hline $\begin{array}{l}\text { Total Aerobic count } \\
\text { (log CFU/g) }\end{array}$ & $4.81 \pm 0.05^{\mathrm{a}}$ & $4.19 \pm 0.07^{\mathrm{ab}}$ & $3.57 \pm 0.06^{b}$ & $3.01 \pm 0.04^{\mathrm{bc}}$ & $2.47 \pm 0.05^{c}$ \\
\hline $\begin{array}{l}\text { Coliform count } \\
\text { (log CFU/g) }\end{array}$ & $2.09 \pm 0.02^{\mathrm{a}}$ & $1.87 \pm 0.03^{\mathrm{ab}}$ & $1.60 \pm 0.00^{b}$ & $1.28 \pm 0.01^{\mathrm{bc}}$ & $1.03 \pm 0.02^{c}$ \\
\hline $\begin{array}{l}\text { Enterobacteriaceae count } \\
\text { (log CFU/g) }\end{array}$ & $1.67 \pm 0.01^{\mathrm{a}}$ & $1.43 \pm 0.00^{\mathrm{ab}}$ & $1.28 \pm 0.03^{b}$ & $1.16 \pm 0.02^{\mathrm{bc}}$ & $1.01 \pm 0.01^{c}$ \\
\hline
\end{tabular}

Values were the mean of three replications; Values in row followed by the same letter $/ \mathrm{s}$ were not differed significantly $(\alpha=P=0.05)$

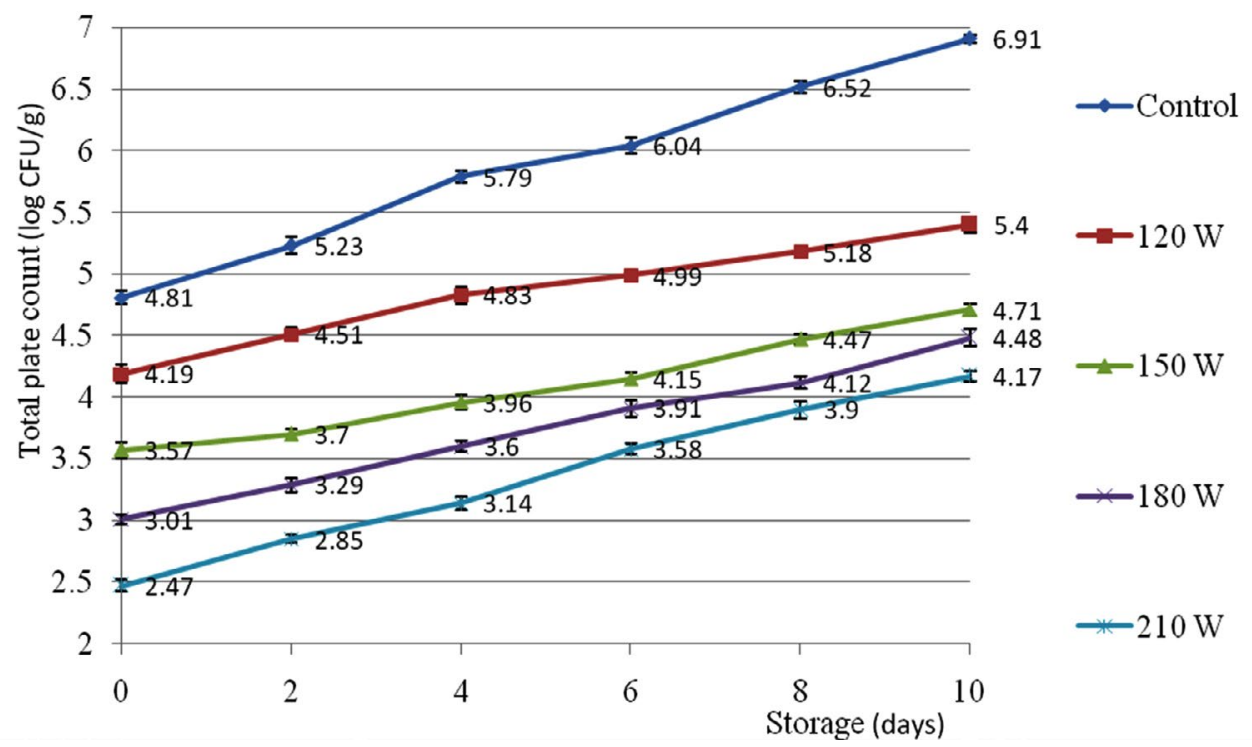

Fig. 1. Total Aerobic count (log CFU/g) of Enoki mushroom pretreated by corona discharge plasma power (W) 
accumulation thus limiting senescence..$^{50}$ Short plasma treatment duration caused no significant difference on ascorbic acid content in treated fruits and vegetables. ${ }^{51}$ Ascorbic acid loss of freshcut fruit and vegetable was noticed by plasma treatment. ${ }^{52}$ Applied voltage and treatment duration had significant impact on the ascorbic acid content. ${ }^{53}$ No significant reduction of ascorbic acid content in kiwifruit after plasma treatment. ${ }^{54}$ The stability of cherry tomatoes was greatly prolonged while organoleptic attributes was maintained in a reasonable degree after corona discharge plasma treatment. ${ }^{55}$

Plasma treatment retained the $95 \%$ ascorbic acid in beverage. ${ }^{56} 96 \%$ retention of ascorbic acid content in banana was noticed after plasma treatment. ${ }^{57}$ Decomposition of ascorbic acid could be due to the reaction of reactive plasma species, light sensitive oxidation during the treatment. ${ }^{58-59}$

\section{Microbial load}

\section{Total Aerobic count}

The effect of corona discharge plasma power (control, 120, 150, 180, $210 \mathrm{~W}$ ) on the total plate count of Enoki mushroom was reported in Fig. 1. There was increasing trend of total plate count during storage. The lowest total Aerobic count was noticed on Enoki mushroom pretreated at $210 \mathrm{~W}(2.47 \pm 0.05$ to $4.17 \pm 0.04 \log$ CFU/g) while the highest total Aerobic count was shown on

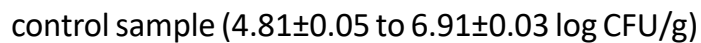
at day zero ( $f 4)$. There was significant difference of total plate count between the control sample and sample pretreated at $150 \mathrm{~W}$. Although treatment at $210 \mathrm{~W}$ showed the lowest total Aerobic count, we did not choose this parameter for application as it would negative impact to physicochemical attributes of Enoki mushroom (as presented in above experiments). Under the treatment of corona discharge plasma power $150 \mathrm{~W}$, the total Aerobic count of Enoki mushroom increased from $3.57 \pm 0.06 \log \mathrm{CFU} / \mathrm{g}$ at the initial day to $4.71 \pm 0.05$ $\log$ CFU/g at the $10^{\text {th }}$ day.

\section{Coliform}

The influence of corona discharge plasma power (control, 120, 150, 180, $210 \mathrm{~W}$ ) on the Coliform load of Enoki mushroom was presented in Fig. 2. There was gradual ascending trend of Coliform load during storage. The lowest Coliform load was noticed on Enoki mushroom pretreated at $210 \mathrm{~W}(1.03 \pm 0.02$ to $2.08 \pm 0.03 \mathrm{log} \mathrm{CFU} / \mathrm{g})$ while the highest Coliform was shown on control sample (2.09 \pm 0.02 to $3.98 \pm 0.02 \log \mathrm{CFU} / \mathrm{g})$ at day zero (table 4). There was significant difference of Coliform between the control sample and sample pretreated at $150 \mathrm{~W}$. Under the treatment of corona discharge plasma power $150 \mathrm{~W}$, the Coliform of Enoki mushroom increased from $1.60 \pm 0.01 \log \mathrm{CFU} / \mathrm{g}$ at the initial day to $3.17 \pm 0.02$ $\log$ CFU/g at the $10^{\text {th }}$ day.

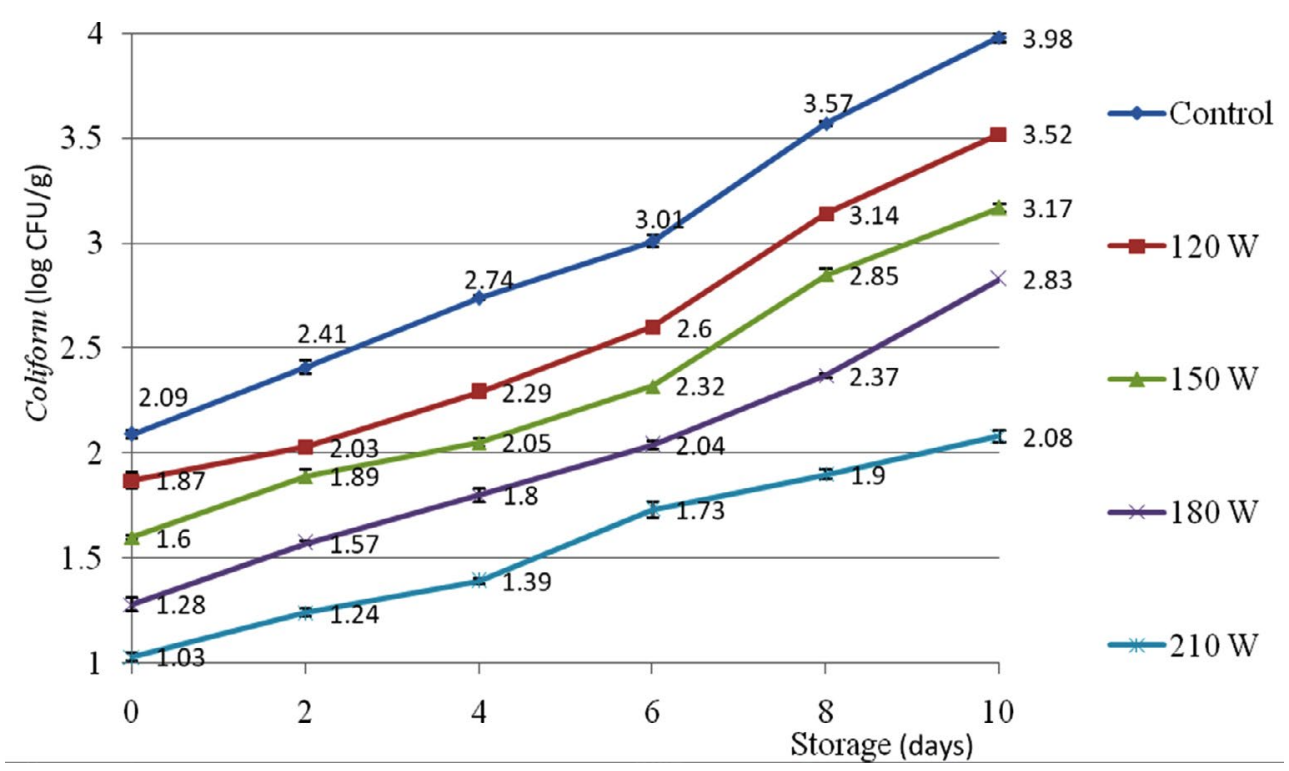

Fig. 2. Coliform (log CFU/g) of Enoki mushroom pretreated by corona discharge plasma power (W) 


\section{Enterobacteriaceae}

The impact of corona discharge plasma power (control, 120, 150, 180, $210 \mathrm{~W}$ ) on the Enterobacteriaceae load of Enoki mushroom was presented in Fig. 3. There was gradual ascending trend of Enterobacteriaceae load during storage. The lowest Enterobacteriaceae load was noticed on Enoki mushroom pretreated at 210 W $(1.01 \pm 0.01$ to $1.73 \pm 0.02 \log \mathrm{CFU} / \mathrm{g})$ while the highest Enterobacteriaceae was shown on control sample $(1.67 \pm 0.01$ to $2.60 \pm 0.03 \log \mathrm{CFU} / \mathrm{g})$ at day zero (table 4). There was significant difference of Enterobacteriaceae between the control sample and sample pretreated at $150 \mathrm{~W}$. Under the treatment of corona discharge plasma power 150 $\mathrm{W}$, the Enterobacteriaceae of Enoki mushroom increased from $1.28 \pm 0.00 \mathrm{log} \mathrm{CFU} / \mathrm{g}$ at the initial day to $2.13 \pm 0.01 \log$ CFU/g at the $10^{\text {th }}$ day.

Table 4 showed the impact of corona discharge plasma to microbiological criteria like total Aerobic count, coliform and Enterobacteriaceae count of Enoki mushroom at day zero. Mechanism of microbial inactivation could be due to emission of reactive oxygen and nitrogen species showing a strong antimicrobial validity by hurting macromolecules via oxidizing proteins, nucleic acids, and lipids. Radiation emitted from corona discharge also could demolish the microbial membranes, structural cell operation and genetic ingredient of pathogens..$^{48}$ Moreover, microorganism were abrasive by cell shooting of electrical elements, disrupting the proper chemical links and widening the cell membrane to the intrusion of reactive species into the internal body of microbe. Molecular pieces were formed inducing to morphological modification of the tissue, and oxidation of cytoplasmic membrane, protein and DNA hence ending microbial inactivation. ${ }^{60}$ The antimicrobial effect of the plasma treatment greatly relied on the layer texture and layer to volume proportion of the sample. ${ }^{11,60}$ Different literatures mentioned the effectiveness of plasma treatment to microbial decontamination. A significant reduction of Pseudomonas load was noticed after 10 min plasma treatment. ${ }^{61}$ Listeria monocytogenes in ham was inactivated by 2 log after plasma treatment. ${ }^{62}$ In another report, Bacillus subtilis spores were completely inhibited by low plasma power density in short treatment duration. ${ }^{63}$ Some spoilage and pathogenic microorganisms colonized on the food surfaces to form biofilm. Biofilm elimination could be achieved by attacking extracellular substrate, cells and cell accessories, and thinning biofilm covering. ${ }^{60}$ Plasma treatment had little impact on biofilm removal. ${ }^{64}$ Besides, high dosage of plasma treatment made protein denaturation leading to inhibition of thermophilic bacteria..$^{49} 45 \mathrm{~s}$ plasma treatment significantly inactivated aerobic microorganisms on blueberries. ${ }^{65}$ Respiration rate of button mushroom was effectively retarded with a delay in softening and better shelf-life extension without

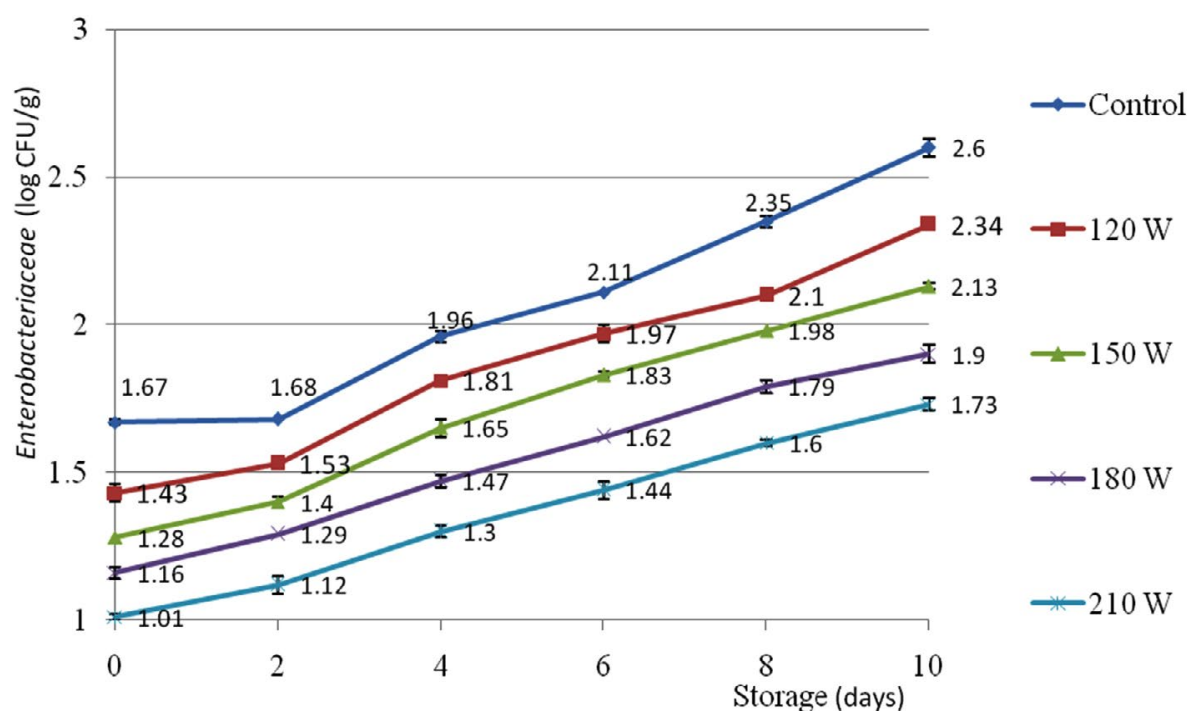

Fig. 3. Enterobacteriaceae (log CFU/g) of Enoki mushroom pretreated by corona discharge plasma power (W) 
any serious impact on color, acidity, antioxidant capability after plasma treatment. ${ }^{41}$ Enterobacter aerogenes on fruit was remarkably inactivated by acidified buffer previously initiated by plasma treatment. ${ }^{66}$ Plasma treatment preserved higher contents of total soluble solid and ascorbic acid in Shiitake mushroom. ${ }^{67}$ Pressure plasma was effective in inactivation of microorganism on mushroom surface with $60-75 \%$ reduction of Escherichia coli. ${ }^{42}$

\section{CONCLUSION}

Corona discharge plasma technology was effective to achieve food stability at ambient or sub-lethal temperatures to minimize the negative thermal impacts on the bioactive ingredients. The most important advantages of corona discharge plasma treatment in this research we could see that there was minimal water usage, free from hazardous solvents or preservatives. Corona discharge plasma treatment should be conducted at power $150 \mathrm{~W}$, treatment time $3 \mathrm{~min}$ and oxygen flow rate $0.6 \mathrm{~mL} / \mathrm{min}$ to maintain physicochemical properties of weight loss, total soluble solid, ascorbic acid while slowing down microbial proliferation of total Aerobic count, Coliform and Enterobacteriaceae during 10 days of ambient storage.

\section{ACKNOWLEDGMENT}

I would like to express my heartfelt thanks to Dr. Nguyen Hong Tuoi for providing assistance on methods. I am also grateful to Mrs Tran Thi Kieu Oanh for English editing of the manuscript.

\section{FUNDING}

This study was supported by Thu Dau Mot University, Binh Duong province, Vietnam.

\section{DATA AVAILABILITY}

All datasets generated or analyzed during this study were included in the manuscript.

\section{ETHICS STATEMENT}

This article did not contain any studies with human participants or animals performed by the author.

\section{REFERENCES}

1. Metanee N, Srisuwan N, Phisit S, Yuthana P, Dheerawan
B, Pilairuk I. Effects of plasma treatment on cooking and physical qualities of pigmented Thai rice. Chiang Mai University Journal of $\mathrm{N}$ at u ra I Sciences. 2021;20:e2021004. doi: 10.12982/CMUJNS.2021.004

2. Domonkos M, Ticha P, Trejbal J, Demo P. Applications of cold atmospheric pressure plasma technology in medicine, agriculture and food industry. Applied Science. 2021;11:4809. doi: 10.3390/app11114809

3. Sarangapani $C$, Thirumdas $R$, Devi $Y$, Trimukhe A, Deshmukh RR, Annapure US. Effect of lowpressure plasma on physico-chemical and functional properties of parboiled rice flour. LWT-Food Science and Technology. 2016;69:482-489. doi: 10.1016/j. Iwt.2016.02.003

4. Joye IJ, Lagrain B, Delcour JA. Use of chemical redox agents and exogenous enzymes to modify the protein network during breadmaking-a review. Journal of Cereal Science. 2009;50:11-21. doi: 10.1016/j. jcs.2009.04.001

5. Jiafeng $J$, Xin $H$, Ling $L$, et al. Effect of cold plasma treatment on seed germination and growth of wheat. Plasma Science and Technology. 2014;16:54. doi: 10.1088/1009-0630/16/1/12

6. Dobrin D, Magureanu M, Mandache NB, Ionita MD. The effect of non-thermal plasma treatment on wheat germination and early growth. Innovative Food Science and Emerging Technologies. 2015;29:255-260. doi: 10.1016/j.ifset.2015.02.006

7. Los A, Ziuzina D, Boehm D, Cullen PJ, Bourke P. Investigation of mechanisms involved in germination enhancement of wheat (Triticum aestivum) by cold plasma: Effects on seed surface chemistry and characteristics. Plasma Processes and Polymers. 2019;16:1800148. doi: 10.1002/ppap.201800148

8. Scholtz V, Sera B, Khun J, Sery M, Julak J. Effects of nonthermal plasma on wheat grains and products. Journal of Food Quality. 2019;2019:7917825. doi: 10.1155/2019/7917825

9. Minh NP. Effectiveness of atmospheric cold plasma technology on physicochemical and functional characteristics of ST25 fragrant rice (Oryza sativa L.) flour. Plant Science Today. 2021;8(3):688-692. doi: 10.14719/pst.2021.8.3.1291

10. Mandal R, Singh A, Singh AP. Recent developments in cold plasma decontamination technology in the food industry. Trends Food Science Technology. 2018;80:93103. doi: 10.1016/j.tifs.2018.07.014

11. Hertwig C, Meneses N, Mathys A. Cold atmospheric pressure plasma and low energy electron beam as alternative nonthermal decontamination technologies for dry food surfaces: A review. Trends Food Science Technology. 2018;77:131-142. 269. doi: 10.1016/j. tifs.2018.05.011

12. Filipic A, Gutierrez-Aguirre I, Primc G, Mozetic M, Dobnik D. Cold plasma, a new hope in the field of virus inactivation. Trends Biotechnology. 2020;38:12781291. doi: 10.1016/j.tibtech.2020.04.003

13. Julak J, Souskova H, Scholtz V, Kvasnickova E, Savicka $D$, Kriha V. Comparison of fungicidal properties of non-thermal plasma produced by corona discharge and dielectric barrier discharge. Folia Microbiology. 2018;63:63-68. doi: 10.1007/s12223-017-0535-6 
14. Borhani A, Badalyan S, Garibyan N, Mosazadeh S, Yasari E. Flammulina Velutipes (Curt.: Fr.) singer: An edible mushroom in northern forest of Iran and its antagonistic activity against selected plant pathogenic fungi. International Journal of Biology. 2011;3(2):162167. doi: 10.5539/ijb.v3n2p162

15. Gallaher DD, Hassel CA, Lee KJ. Relationships between viscosity of hydroxypropyl methylcellulose and plasma cholesterol in hamsters. Journal of Nutrition. 1993;123(10):1732-1738. doi: 10.1093/ jn/123.10.1732

16. Knopp RH, Superko HR, Davidson M, et al. Long-term blood cholesterol-lowering effects of a dietary fiber supplement. The American Journal of Preventive Medicine. 1999;17(1):18-23. doi: 10.1016/s07493797(99)00039-2

17. Levrat-Verny M, Behr S, Mustad V, Remesy C, Demigne C. Low levels of viscous hydrocolloids lower plasma cholesterol in rats primarily by impairing cholesterol absorption. Journal of Nutrition. 2000;130(2):243-248. doi: $10.1093 / \mathrm{jn} / 130.2 .243$

18. Ikekawa T. Beneficial effects of edible and medicinal mushrooms on health care. International Journal of Medical Mushroom. 2001;3:291-298. doi: 10.1615/ IntJMedMushr.v3.i4.20

19. Sano M, Yoshino K, Matsuzawa T, Ikakawa T. Inhibitory effects of edible higher Basidiomycetes mushroom extracts on mouse type IV allergy. International Journal of Medicinal Mushrooms. 2002;4(1):37-41. doi: 10.1615/IntJMedMushr.v4.i1.40

20. Cai HH, Liao ST, Ye YS, Liu XM. Advances in studies on components, bioactivity and processing of Flammulina velutipes. Food Research and Development. 2008;29(11):171-175.

21. Chang HH, Hsieh KY, Yeh CH, Tu YP, Sheu F. Oral administration of an Enoki mushroom protein FVE activates innate and adaptive immunity and induces anti-tumor activity against murine hepatocellular carcinoma. International Immunopharmacology. 2010;10:239-246. doi: 10.1016/j.intimp.2009.10.017

22. Tang C, Hoo PCX, Tan LTH, et al. Golden needle mushroom: A culinary medicine with evidenced-based biological activities and health promoting properties. Frontiers Pharmacology. 2016;7:474. doi: 10.3389/ fphar.2016.00474

23. Miettinen TA, Gylling H. Regulation of cholesterol metabolism by dietary plant sterols. Current Opinion in Lipidology. 1999;10(1):9-14. doi: 10.1097/00041433199902000-00003

24. Hertog MGL, Hollman PCH, Katan MB, Kromhout D. Intake of potentially anticarcinogenic flavonoids and their determinants in adults in The Netherlands. Nutrition and Cancer. 1993;20(1):21-29. doi: 10.1080/01635589309514267

25. Anderson JW, Jones AE, Riddell-Mason S. Ten different dietary fibers have significantly different effects on serum and liver lipids of cholesterol-fed rats. Journal of Nutrition. 1994;124(1):78-83. doi: 10.1093/ jn/124.1.78

26. Okamura M. Distribution of ascorbic acid analogs and associated glycosides in mushrooms. Journal of Nutritional Science and Vitaminology. 1994;40(2):81-
94. doi: $10.3177 /$ jnsv.40.81

27. Ming-Yei Y, Wen-Ching K, Li-Yun L. Hypolipidemic and antioxidant activity of Enoki mushrooms (Flammulina velutipes). BioMed Research International. 2014;2014:352385. doi: 10.1155/2014/352385

28. McClure PJ, Hall S. Survival of Escherichia coli in foods. Joumal of Applied Microbiology Symposium Supplement.2000:88:61S-70S. doi: 10.1111/j.13652672.2000.tb05333.x

29. Manijeh M, Mohammad J, Roha KK. Biofilm formation by Salmonella enteritidis on food contact surfaces. Journal of Biology Sciencce. 2008;8:502-505. doi: 10.3923/jbs.2008.502.505

30. Buchanan RL, Gorris LG, Hayman MM, Jackson TC, Whiting RC. A review of Listeria monocytogenes: An update on outbreaks, virulence, dose-response, ecology, and risk assessments. Food Control. 2017;75:1-13. doi: 10.1016/j.foodcont.2016.12.016

31. Mahajan PV, Caleb OJ, Singh Z, Watkins CB, Geyer M. Postharvest treatments of fresh produce. Philosophical Transactions of the Royal Society A Mathematic Physical and Engineering Science. 2014;372:20130309. doi: 10.1098\%2Frsta.2013.0309

32. Bermudez-Aguirre $A$, Wemlinger $E$, Pedrow $P$, Barbosa-Canovas G, Garcia-Perez M. Effect of atmospheric pressure cold plasma (APCP) on the inactivation of Escherichia coli in fresh produce. Food Control. 2013;34:149-157. doi: 10.1016/j. foodcont.2013.04.022

33. Pasquali F, Stratakos AC, Koidis A, et al. Atmospheric cold plasma process for vegetable leaf decontamination: $A$ feasibility study on radicchio (red chicory, Cichorium intybus L.). Food Control. 2016;60:552-559. doi: 10.1016/j.foodcont.2015.08.043

34. Siddique SS, Hardy GESJ, Bayliss KL. Cold plasma: A potential new method to manage postharvest diseases caused by fungal plant pathogens. Plant Pathology. 2018;67:1011-1021. doi: 10.1111/ppa.12825

35. Pan Y, Cheng JH, Sun DW. Cold plasma-mediated treatments for shelf life extension of fresh produce: A review of recent research developments. Comprehensive Review of Food Science and Food Safety. 2019;18:1312-1326. doi: 10.1111/15414337.12474

36. Lopez $\mathrm{M}$, Calvo $\mathrm{T}$, Prieto $\mathrm{M}$, et al. A review on nonthermal atmospheric plasma for food preservation: Mode of action, determinants of effectiveness, and applications. Frontiers Microbiology. 2019;10:622. doi: 10.3389/fmicb.2019.00622

37. Misra NN, Yepez X, Xu L, Keener K. In-package cold plasma technologies. Journal of Food Engineering. 2019;244:21-31. doi: 10.1016/j.jfoodeng.2018.09.019

38. Xiang Q, Liu X, Liu S, Ma Y, Xu C, Bai Y. Effect of plasma-activated water on microbial quality and physicochemical characteristics of mung bean sprouts. Innovative Food Science Emerging Technology. 2019;52:49-56. doi: 10.1016/j.ifset.2018.11.012

39. Seo H, Hong J, Woo J, et al. Potential of non-thermal N2 plasma-treated buffer (NPB) for inhibiting plant pathogenic bacteria and enhancing food storage. LWT-Food Science Technology. 2020;125:109210. doi: 10.1016/j.Iwt.2020.109210 
40. Sakudo A, Yagyu Y. Application of a roller conveyer type plasma disinfection device with fungus-contaminated citrus fruits. AMB Express. 2021;11:16. doi: 10.1186/ s13568-020-01177-2

41. Xu Y, Tian $Y, M a R$, Liu Q, Zhang J. Effect of plasma activated water on the postharvest quality of button mushrooms, Agaricus bisporus. Food Chemistry. 2016;197:436-444. doi: 10.1016/j. foodchem.2015.10.144

42. Mitra S, Veerana M, Choi EH, Park G. Effects of pre-treatment using plasma on the antibacterial activity of mushroom surfaces. Foods. 2021;10:1888. doi: 10.3390/foods10081888

43. Nikiforov $A$, Deng $X$, Xiong $Q$, et al. Non-thermal plasma technology for the development of antimicrobial surfaces: A review. Journal of Physics D: Applied Physics. 2016;49:204002. doi: 10.1088/0022$3727 / 49 / 20 / 204002$

44. Jeong WS, Kwon JS, Choi EH, Kim KM. The effects of non-thermal atmospheric pressure plasma treated titanium surface on behaviors of oral soft tissue cells. Scientific Reports. 2018;8:15963. doi: 10.1038/s41598018-34402-x

45. Moriguchi $Y$, Lee DS, Chijimatsu R, et al. Impact of non-thermal plasma surface modification on porous calcium hydroxyapatite ceramics for bone regeneration. PLOS ONE. 2018;13:e0194303. doi: 10.1371/journal.pone.0194303

46. Lee MJ, Kwon JS, Jiang HB, Choi EH, Park G, Kim KM. The antibacterial effect of non-thermal atmospheric pressure plasma treatment of titanium surfaces according to the bacterial wall structure. Scientific Reports. 2019;9:1938. doi: 10.1038/s41598-01939414-9

47. Pankaj SK, Wan Z, Keener KM. Effects of cold plasma on food quality: A review. Foods. 2018;7:4. doi: $10.3390 \% 2$ Ffoods7010004

48. Varilla C, Marcone M, Annor GA. Potential of cold plasma technology in ensuring the safety of foods and agricultural produce: a review. Foods. 2020;9:1435. doi: 10.3390/foods9101435

49. Attri P, Han J, Choi S, Choi EH, Bogaerts A, Lee W. CAP modifies the structure of a model protein from thermophilic bacteria: Mechanisms of CAP-mediated inactivation. Scientific Reports. 2018;8:10218. doi: 10.1038/s41598-018-28600-w

50. Takaki K, Takahashi K, Hamanaka D, Yoshida R, Uchino T. Function of plasma and electrostatics for keeping quality of agricultural produce in postharvest stage. Japanese Journal of Applied Physics. 2021;60(1):010501. doi: 10.35848/1347-4065/abcc13

51. Oehmigen $K$, Hahnel M, Brandenburg R, Wilke C, Weltmann KD, Woedtke T. The role of acidification for antimicrobial activity of atmospheric pressure plasma in liquids. Plasma Processes and Polymers. 2010;7:250-257. doi: 10.1002/ppap.200900077

52. Wang R, Nian WF, Wu HY, et al. Atmospheric-pressure cold plasma treatment of contaminated fresh fruit and vegetable slices: Inactivation and physiochemical. properties evaluation. The European Physical Journal. 2012;66(10):276. doi: 10.1140/epjd/e2012-30053-1

53. Misra NN, Pankaj SK, Frias JM, Keener KM, Cullen
PJ. The effects of nonthermal plasma on chemical quality of strawberries. Postharvest Biology and Technology. 2015;110:197-202. doi: 10.1016/j. postharvbio.2015.08.023

54. Ramazzina I, Berardinelli A, Rizzi F, et al. Effect of cold plasma treatment on physico-chemical parameters and antioxidant activity of minimally processed kiwifruit. Postharvest Biology and Technology. 2015;107:55-65. doi: 10.1016/j.postharvbio.2015.04.008

55. Lee T, Puligundla P, Mok C. Intermittent corona discharge plasma jet for improving tomato quality. Journal of Food Engineering. 2018;223:168-174. doi: 10.1016/j.jfoodeng.2017.11.004

56. Mehta D, Sharma N, Bansal V, Sangwan RS, Yadav SK. Impact of ultrasonication, ultraviolet and atmospheric cold plasma processing on quality parameters of tomato-based beverage in comparison with thermal processing. Innovative Food Science and Emerging Technologies. 2019;52:343-349. doi: 10.1016/j. ifset.2019.01.015

57. Trivedi MH, Patel K, Itokazu H. Enhancing shelf life of bananas by using atmospheric pressure pulsed cold plasma treatment of the storage atmosphere. Plasma Medicine. 2019;9(1):23-28. doi: 10.1615/ PlasmaMed.2019026909

58. Helgadottir S, Pandit S, Mokkapati VR, Westerlund F, Apell P, Mijakovic I. Vitamin C pretreatment enhances the antibacterial effect of cold atmospheric plasma. Frontiers in Cellular and Infection Microbiology. 2017;7:43. doi: 10.3389/fcimb.2017.00043

59. Hadi B, Sepideh A. Effect of cold plasma on quality retention of fresh-cut produce. Journal of Food Quality. 2020;2020:8866369. doi: 10.1155/2020/8866369

60. Bourke P, Ziuzina D, Han L, Cullen P, Gilmore BF. Microbiological interactions with cold plasma. J Appl Microbiol. 2017;123:308-324. doi: 10.1111/jam.13429

61. Giannoglou M, Stergiou P, Dimitrakellis P, Gogolides E, Stoforos NG, Katsaros G. Effect of cold atmospheric plasma processing on quality and shelf-life of readyto-eat rocket leafy salad. Innovative Food Science Emerging Technology. 2020;66:102502. doi: 10.1016/j. ifset.2020.102502

62. Yadav B, Spinelli AC, Misra NN, Tsui YY, McMullen LM, Roopesh M. Effect of in-package atmospheric cold plasma discharge on microbial safety and quality of ready-to-eat ham in modified atmospheric packaging during storage. Journal of Food Science. 2020;85:12031212. doi: 10.1111/1750-3841.15072

63. Pina-Perez $M$, Martinet $D$, Palacios-Gorba C, Ellert C, Beyrer M. Low-energy short-term cold atmospheric plasma: Controlling the inactivation efficacy of bacterial spores in powders. Food $R$ e $s$ e $a r c h$ International. 2020;130:108921. doi: 10.1016/j. foodres.2019.108921

64. El Kadri H, Costello KM, Thomas P, et al. The antimicrobial efficacy of remote cold atmospheric plasma effluent against single and mixed bacterial biofilms of varying age. Food Research International. 2021;141:110126. doi: 10.1016/j.foodres.2021.110126

65. Lacombe A, Niemira BA, Gurtler JB, et al. Atmospheric cold plasma inactivation of aerobic microorganisms on blueberries and effects on quality attributes. 
Food Microbiology. 2015;46:479-484. doi: 10.1016/j. fm.2014.09.010

66.

Joshi I, Salvi D, Schaffner DW, Karwe MV. Characterization of microbial inactivation using plasma-activated water and plasma-activated acidified buffer. Journal of Food Protection. 2018;81:1472-1480. doi: 10.4315/0362-028x.jpp-17-487
67.

Karim N, Shishir MRI, Bao T, Chen W. Effect of cold plasma pretreated hot-air drying on the physicochemical characteristics, nutritional values and antioxidant activity of shiitake mushroom. Journal of the Science of Food and Agriculture. 2021;101:62716280. doi: 10.1002/jsfa.11296 